\title{
Sonja Svoljšak
}

\section{Gašper Žitnik in njegove knjige}

\begin{abstract}
Ključne besede: Gašper Žitnik, osebne knjižne zbirke, rokopisne zabeležke, 16. stoletje
\end{abstract}

DOI: 10.4312/ars.8.2.131-148

\section{Uvod}

Gašper Žitnik (ok. 1535-1585) je bil pomembna in vplivna zgodovinska osebnost, pa vendar je bilo o njem zapisanega bolj malo. Bil je pravnik, palatinski grof in svetnik notranjeavstrijske deželne vlade. Kot štipendist Brikcija Preprostega (?-1505) se je 14. aprila 1555 vpisal na dunajsko univerzo, kjer je marca 1560 dosegel artistični bakalavreat, junija 1563 magisterij, kasneje pa bil promoviran še za doktorja obojega prava. Leta 1570 je bil imenovan za štajerskega vladnega svetnika. Pri posameznih protireformacijskih ukrepih in akcijah je sodeloval tudi s kranjskim deželnim glavarstvom, predvsem pa je njegovo delo izredno cenil štajerski deželni knez, nadvojvoda Karel. Še pomembnejši je bil njegov vpliv na nečaka in kasnejšega ljubljanskega škofa Tomaža Hrena (1560-1630), saj je poskrbel za njegovo vzgojo in izobraževanje, pomagal pa je tudi pri začetkih njegove kariere. Leta 1568 ga je vzel k sebi na Dunaj, naslednje leto pa ga je poslal v admontski samostan, da bi ga obvaroval pred kugo. Leta 1573 ga je poslal na šolanje k jezuitom v Gradec (Valenčič, 1991, 976).

V študentskih letih se je Žitnik ukvarjal tudi s pesnjenjem. Napisal je nekaj hvalnic ter priložnostnih pesnitev ob porokah in pogrebih (J. Straussu, grofu Zrinjskemu, Maksimilijanu II., J. Reucheliju, J. Ubermannu in Luki iz Dobrepolja) (Simoniti, 1972, 132). Da je bil tudi navdušen bralec, pa pričajo številne knjige z njegovim podpisom in drugimi zabeležkami, ki jih je vse življenje kupoval, prejemal $\mathrm{v}$ dar ali podarjal.

Žitnikove knjige je najkasneje po njegovi smrti leta 1585 nasledil Tomaž Hren (Vidmar, 2012, 237), do leta 1789, ko so bile v skladu z odlokom štajerskega gubernija predane v nekdanjo licejsko knjižnico, pa so bile shranjene v Gornjem Gradu (Stefan, 2009, 28). Danes so del Zbirke redkih in starih tiskov ter Kartografske zbirke Narodne in univerzitetne knjižnice. Od leta 1974 do danes je bilo v Narodni in univerzitetni knjižnici odkritih 94 del v 30 zvezkih, za katere lahko rečemo, da 
so bile v Žitnikovi lasti. Nekaj njegovih knjig, kot na primer Tractatus de actionibus Kalvinovega tajnika Françoisa Hotmana iz leta 1548 (Vidmar, 2012, 237), pa je prek zamenjav v 18. stoletju prišlo tudi v Semeniško knjižnico. Štiri inkunabule ter kompilacija pesnitev, govorov in drugih drobnih tiskov s provizoričnim naslovom Miscellanea selectissima so omenjene $\mathrm{v}$ Gspanovem in Badalićevem katalogu Inkunabule v Sloveniji (1957, 149, 171, 173 in 220), v Simonitijevi analizi Terpinovega kataloga iz gornjegrajske škofijske knjižnice (2007, 271-315), v Simonitijevi knjigi Humanizem na Slovenskem $(1979,133)$ in v bibliografiji Sloveniae scriptores latini recentioris aetatis ... istega avtorja (Simoniti, 1972). Ena Žitnikova knjiga je omenjena tudi v članku N. Golob Reflections on some expressions of Bohemian art around 1400 in Slovenia $(2012,60)$ ter v knjigi Provenience starih tiskov Narodne in univerzitetne knjižnice (Svoljšak in Kocjan, 2013, 29). Celotna zbirka sicer še ni dokončno raziskana. ${ }^{1}$

Gašper Žitnik se je zelo rad podpisoval v svoje knjige, vanje pa je v razmeroma dobro čitljivi humanistični kurzivi v rjavi ali črni tinti zapisoval tudi različne opombe, komentarje, citate, izreke in druga besedila. V njegovih knjigah so tudi številne zabeležke ter zaznamki drugih oseb in ustanov.

V prispevku predstavljam rokopisne dodatke, ki jih vsebujejo Žitnikove knjige $\mathrm{v}$ Narodni in univerzitetni knjižnici. Ti so sistematizirani glede na sporočilnost in izvor oziroma avtorstvo. Na podlagi pregleda in analize podatkov ter $\mathrm{v}$ kombinaciji z obstoječimi biografskimi podatki skušam razbrati kakšno dodatno podrobnost o Žitnikovem zasebnem in poklicnem življenju oziroma razmerju med njim in njegovimi knjigami ter tako nadgraditi do sedaj znane podatke o njegovem življenju in delu. Prispevku dodajam tudi bibliografijo do sedaj odkritih Žitnikovih knjig iz Narodne

1 Temeljno delo slovenske inkunabulistike omenja štiri Žitnikove inkunabule, ki pa jih napačno pripisuje Gašperju Lipniku (Gspan in Badalić, 1957, 490), v Simonitijevi adendi k popisu inkunabul na Slovenskem pa ni navedene nobene Žitnikove knjige (2007, 316-333). Da so bile Žitnikove knjige hranjene v Gornjem Gradu, potrjujejo tudi Simonitijeve ugotovitve ob pregledu nekdanjih Budinovih, Seebachovih, Radličevih, Tavčarjevih in Žitnikovih knjig v Narodni in univerzitetni knjižnici in Semeniški knjižnici, ki je bil opravljen na podlagi Terpinovega kataloga gornjegrajske škofijske knjižnice iz leta 1655 (Simoniti, 2007, 271-315). Žitnikove knjige omenja tudi Južnič (Južnič, 2008). Ena izmed knjig je v licejsko knjižnico najverjetneje prišla po razpustitvi kranjske deželne vlade in vsebuje tudi njen žig (K. K. Landesregierung des Herzogthumes Krain). Gre za pomemben in večkrat ponatisnjen kompendij s področja fevdalnega prava »Tractatus insignis de reintegratione feudorum ... «Parida iz Pozza (1413-1493). Vezan je v razkošno iluminiran bifolij srednjeveškega rokopisa (Golob, 2012, 60). Ena Žitnikova knjiga je v licejsko knjižnico prišla iz ljubljanskega samostana bosonogih avguštincev. V osrednjem polju sprednje platnice so vtisnjene kratice M. C. S. (Magister Caspar Sitnick?). Vsebuje tudi dve stari signaturi knjižnice bosonogih avguštincev (N 23 in I 2) in je v popisu knjig, ki so bile leta 1786 predane licejski knjižnici, uvrščena v sklop »N« (Humanista allique varii libri sub littera) pod zaporedno številko 23 (Simoniti, 1979, 133 in Bücherkatalog des Diskalzeatenklosters zů Laibach, NUK, Ljubljana, Ms 1944). Sicer je v Zbirki starih tiskov NUK še nekaj knjig, ki so tako kot večina Žitnikovih vezane v nebarvan oziroma rdeče ali zeleno obarvan pergament in vsebujejo lastniški zaznamek gornjegrajske škofijske knjižnice. Morda so bile tudi te nekoč njegove, žal pa ne vsebujejo njegovega podpisa ali druge rokopisne zabeležke, ki bi to dokazovala. 
in univerzitetne knjižnice, ki povzema podatke iz Gspanovega kataloga (1957), Simonitijeve študije Terpinovega kataloga (2007), knjige Humanizem na Slovenskem istega avtorja (1979) in kasnejših sistematičnih pregledov starejših fondov Narodne in univerzitetne knjižnice.

\section{Žitnik o sebi}

Gašper Žitnik se je najpogosteje podpisoval na naslovne strani svojih knjig ali na sprednje spojne liste. Pri tem je uporabljal celotno ime in priimek ali pa je posamezne podatke okrajšal. Tovrstne zabeležke se brez izjeme pričenjajo z glagolom esse v prvi osebi ednine, temu pa sledita njegovo ime in priimek v rodilniku. Občasno je osebnim podatkom dodajal še pojasnila o svojem statusu, izobrazbi in izvoru. V nekatere knjige (npr. Codex Iustiniani) ${ }^{2}$ se je podpisal tudi večkrat. Najpogostejše formulacije, ki jih je uporabljal, so: »Sum M[agistri] Casp[aris] Sitnick«, »Sum Ca[sparis] Sitnikh«, »Sum $\mathrm{Ca}[$ sparis] Sitnichij« in »Sum Caspari Sitnikh«.

Kot magister se je Žitnik podpisoval do leta 1567. V knjigi Ennarationes in sex priores libros Aeneidos Vergiliane Lamberta Hortensia ob imenu, priimku in nazivu navaja še letnico 1567. Prvi zabeležki, ki vsebujeta tudi podatek o njegovem najvišjem akademskem nazivu, sta na naslovni strani Seilerjeve Remissiones, ki je bila natisnjena leta 1571, in na naslovni strani Tritemijeve (Johannes Trithemius = Johann Heidenberg) Chronicon insigne monastarii Hirsaugensis iz leta 1559. V obe je Žitnik zapisal: »Sum Casp[aris] Sitnikh I. V. D.«, temu pa je dodal še moto: »virtus sorte potentior", ki bi ga lahko prevedli kot »odličnost/vrlina je boljša od usode/ stanu «. ${ }^{3}$ V Trithemiusovi kroniki je nad zabeležko zapisal še letnico 1571. Iz tega je mogoče sklepati, da je doktorski naziv pridobil leta 1571 oziroma v letih med 1567 in 1571.

Poleg osnovnih podatkov in svoje izobrazbe je Žitnik v svoje knjige občasno zapisal tudi kakšno podrobnost o svojem izvoru. V Quaestiones super libros Metaphysicae Aristotelis iuxta Thomisticae doctrinae dogmata decisae se je na primer podpisal: "Sum Caspari Sitnigkh Labacen[sis] «, v Tabula Iulii Palamedis Adriensis in Aristotelis, Averroisq[ue] opera pa: »Sum Caspari Sitnigk Labacen[sis] Carni[olensis]. Idibus Novemb[ris] anno 62.«.

2 Za podrobnejše podatke o posamezni knjigi glej dodatek na koncu prispevka.

3 V isti knjigi motu sledi še krajši zapisek, vendar ga predvsem zaradi žiga Licejske knjižnice, ki je deloma odtisnjen čezenj, žal ni mogoče razbrati. 


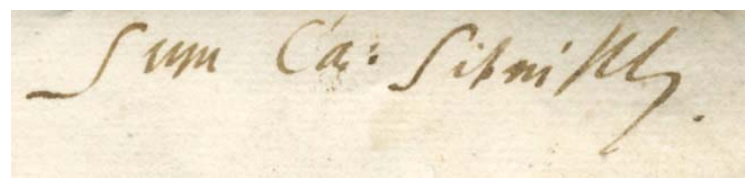

Slika 1: Značilen Žitnikov podpis. V: Paride del Pozzo:

Tractatus insignis de reintegratione feudorum.

GS II 36199 (naslovna stran).

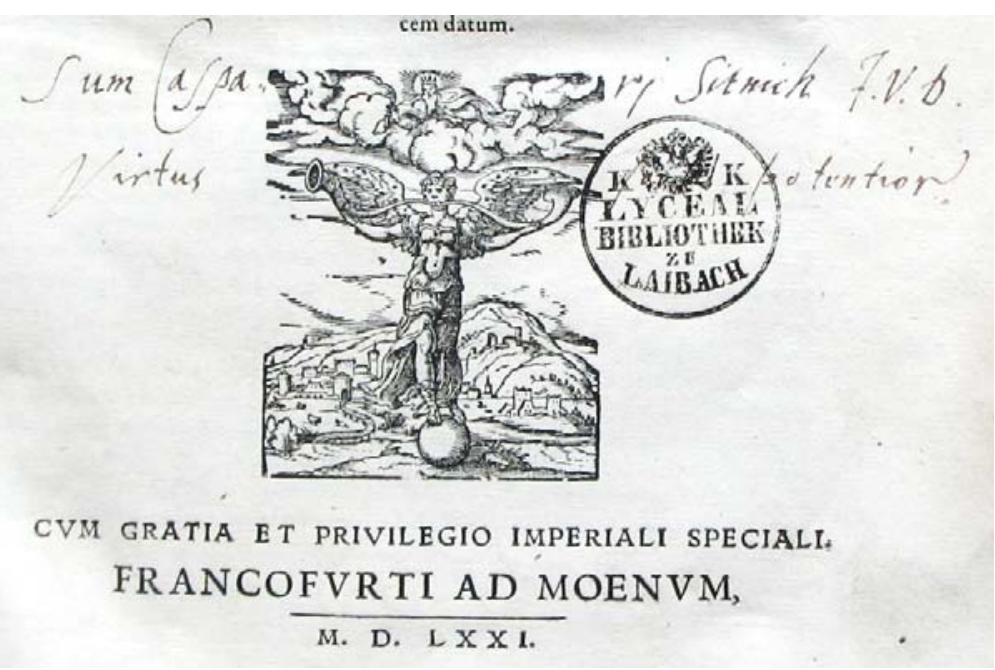

Slika 2: Žitnikov podpis z navedbo doktorskega naziva. V: Seiler, Raphael: Remissiones vel, ut alii commodius dici arbitrantur, relegationes instar mercurialis statuae indicantes.

GS II 17624 (naslovna stran).

\section{Žitnik o svojih knjigah}

Več Žitnikovih knjig vsebuje zaznamke o kraju in letu oziroma dnevu nakupa ali pa zabeležke o darovalcih oziroma obdarjencih. Na sprednji spojni list Porfirijeve knjige Isagoge in dialecticen je tako zapisal, da jo je kupil od Lucasa Schezkaresa: »Casparus Sitnikh Labacen[sis] Carnus. 1558. Emptus est Vienna ... à Luca Schezkario Liberaliu[m] artiu[m] ac phi[losophi]ae baccalauro amico suo plurimu[m] observando«. Kvintilijanova Oratoriarum institutionum libri XII vsebuje zabeležko: "Sum M. Casp: Sitnick«, pod tem pa še: "nunc consobrinus meus Georgius Schriep [?] tenet hunc librum «. Na naslovni strani D'Auvergnovih Postillae maiores totius anni piše: "Sum Caspari Sitnikh 1573 in festo S. Andreae«. V Pomponijevi Libri de situ orbis tres, ki ji je dodanih še šestindvajset ročno narisanih in pobarvanih zemljevidov 
antičnega sveta ter legend in komentarjev P. Freiländerja, pa je Žitnik zabeležil, da jo je prejel v dar od nekega Andreasa: »1571, ex dono Andreae Grund[?]ij«.

Quaestiones super libros Metaphysicae Aristotelis iuxta Thomisticae doctrinae dogmata decisae na naslovni strani vsebuje daljšo zabeležko iz leta 1563. Žitnik je knjigo podaril Mathiasu Lubanusu in zapisal: "Excellentissimo doctissimo[que] viro d[omi]no Matthie Lubano ... M[a]g[iste]r Casparus Sitnikh d[e]d[i]t 1563«. V zgornjem desnem kotu pa najdemo še kratko pripombo: »Emptus Viennae Austriae«.

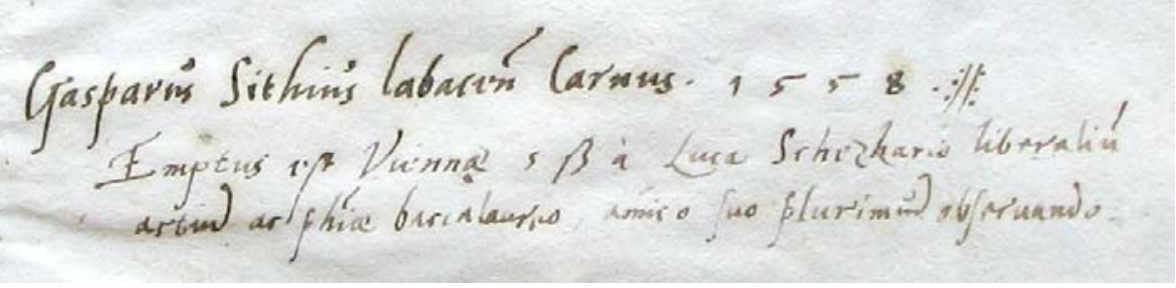

Slika 3: Žitnikova zabeležka o nakupu.

V: Porphyrius: Isagoge in dialecticen.

GS I 742 (sprednji spojni list).

\section{Druge Žitnikove zabeležke, komentarii in citati}

$\mathrm{V}$ katalogu rektorjev dunajske univerze, ki je zvezan skupaj s številnimi priložnostnimi pesnitvami in govori (signatura GS I 6115), najdemo Žitnikove zabeležke pri Konradu iz Hallstatta, Brikciju Preprostemu, Žigi Herbersteinu in Christophoru Kulberju.

V Kasimirjevo Brevis et luculenta expositio causarum, quibus adductus illustriss. princeps ac dominus, dominus Iohannes Casimirus ... hanc expeditionem, ad erigendas res Belgii graviter afflictas, susceperit je Žitnik pod naslovom zabeležil še njegovo skrajšano oziroma poenostavljeno različico: »Opuscula de causa belli Belgici«.

Na sprednjem spojnem listu Epitome Tyrocinii iuris civilis, ki sta ji privezana še dva pravna priročnika, je sedem sentenc $v$ grščini, pod vsako pa je še latinski prevod (npr.: "parentes imprimis honoribus afficias«, "parentes amato quam constantissime«, »audacia principium actionis est, fortuna vero dominatur» in »arduis rebus crescit hominum gloria $)$.

Sprednji spojni list Singularia, praeclarissima ac imprimis omnibus iurisperitis pernecessaria, ac utilissima vsebuje različne izreke, pregovore in citate iz antičnih besedil, pa tudi odlomke iz sv. Hieronima in Sv. pisma (npr.: »raro breves humiles vidi, rufosque fideles, albos audaces, miror longos sapientes«). 
Izjemno veliko Žitnikovih glos vsebuje uradno gradivo za študente dunajske univerze, ki obsega Porfirijev uvod v dialektiko in šest Aristotelovih filozofskih razprav. Nekaj podčrtajev, nota bene, in izpiskov (npr. k dialogu med Mojzesom in Belialom), ki so zagotovo delo Žitnikove roke, pa je tudi v Teramovem Consolatio Peccatorum, seu Processus Belial. Na sprednjem spojnem listu Lagusove Methodica iuris traditio so zapisani trije od desetih korakov pravnega reda (Ordo juris per 10. gradus): »Mens et consensus hominis, Ex consensu dicta aut facta, ex dictis aut factis [contractus vel quasi] «.

Templum omnium iudicium pontificiae, cesareae, regiae, inferiorisque potestatis na drugem praznem predlistu vsebuje daljši zapisek:

Eniteas nitor felix quod Biankha ducissa, hoc subito peperit ruimen, amorq[ue] tibi culpa decus tribuit, culpa data gloria culpae quis culpet, quando tot bona culpa parit.

V zadnjem letu svojega življenja je Žitnik na notranjo stran hrbtne platnice Frischlinovih zbranih dramskih del Operum poeticorum (Strassburg, 1585) zapisal epigram Johanna Lauterbacha o neki deklici (De quadam virgine):

Cur aleret barbam, iuvenem cum virgo rogaret;

Ut retro fugiat territus hostis, ait.

Falleris, illa subit: vanum me teste probabo:

Nunc hirsuta petor, quae glabra tuta fui.

Morda je Žitnik tudi avtor portreta bradatega moškega v zgodnjih srednjih letih, ki nosi visoko pokrivalo ter po svojih dolgih in ostrih obraznih potezah nekoliko spominja na Tomaža Hrena. Risba s peresom je na sprednji platnici Salutatijeve Tractatus de nobilitate legum.

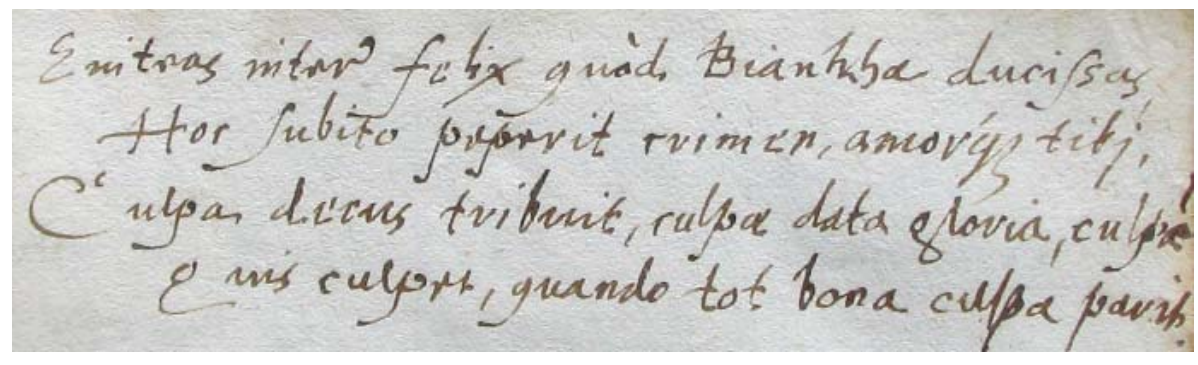

Slika 4: Žitnikova zabeležka o ...

V: Corradi, Lancelotto: Templum omnium iudicum pontificiae, 1575.

GS II 17622 (drugi prazni predlist). 


\section{Zabeležke prejšniih in kasnejših lastnikov Žitnikovih kniig}

V Žitnikovih knjigah lahko preberemo tudi zabeležke nekaterih drugih njegovih sodobnikov. Nekajkrat gre za prejšnje lastnike ali osebe, ki so Žitniku knjige podarile, večinoma pa za kasnejše lastnike. Nekaj tovrstnih zabeležk je tudi prečrtanih, počečkanih ali nečitljivih, zato vsebine ni mogoče razbrati.

Justinijanove Institutiones iuris vsebujejo zabeležko: "Sum ex libris Gerardi N.«, Pomponijeva De situ orbis pa vsebuje ime nekega Wolfganga ter njegovo zabeležko, da je knjigo kupil leta 1568 v Celovcu. Na notranji strani sprednje platnice ter nad pričetkom besedila Lagusove Methodica iuris traditio je poleg Žitnika kot lastnik knjige podpisan še Christophorus Fuerrerius Austriacus (z letnicama 1562 in 1563), ki je na sprednji spojni list zapisal tudi nekaj citatov iz Temistokla. V Porfirijevi Isagoge in dialecticen je na naslovni strani podpisan še Petrus Rabenius Livoniensis, na sprednjem spojnem listu in naslovni strani pa je poleg Žitnika, ki je zapisal izrek: »Fide, sed ante vide, cui tuto fidere possis«, ki ga v različnih oblikah najdemo v zbirkah emblemov oziroma epigramov Nicolasa Reusnerja in Gabriela Rollenhagna, neznana roka dodala še dva izreka iz Horacija: "Nullius addictus iurare in verba magistri«, "quo me cumque rapit tempestas, deferor hospes« in Vergilija: »Invenies alium si te hic fastidit Alexis[!]«.

Avtor pesnitve Epithalamion in nuptias ... viri, DN. Sebastiani Froelich Graecensis Styri [et] honestissimae virginis Marthae Paulus Schedius je na naslovni strani zapisal posvetilo: »Fratri S[uo] carissimo, M[agistri] Casparo Sitnico ... P[aulus] Schedius «. ${ }^{4}$

O povezavi med Žitnikom in Tomažem Hrenom priča zapisek v d'Auvergnovih Postillae maiores totius anni: "Sum Thoma[e] Chrönn Canonici \& Ecc[lesiastae] Labacen[sis].« Temu je dodan še Hrenov moto: »Terret labor, Aspice premium«. Knjiga vsebuje še nekaj Hrenovih zabeležk ob robu besedila, pa tudi pet odlomkov oziroma citatov iz sv. Avguština, Izidorja Seviljskega, sv. Bernarda ter Stare in Nove zaveze, ki jih je Hren zapisal na sprednji spojni list. Na vrhu naslovne strani iste knjige je še zabeležka: »Fui Urbani Episcopi Gurcen[sis]«.

Ker so bile Žitnikove knjige dolgo hranjene v gornjegrajski knjižnici, nekatere izmed njih vsebujejo tudi škofovski lastniški zaznamek: Ex lib[ris] Epi[scopi] Lab[acensis] eiusdemque Bibliotheca[e] Oberburg[ensis] ali Ill[ustrissi]mi et R[everendi]ssimi Pricipis Epi[scopi] Labacensis Bibliotheca Oberburg[ensis]. Skalićeva Encyclopaediae, seu Orbis

4 Zanimivo je tudi tiskano posvetilo Gašperju Žitniku dunajskega tiskarja Stephana Kreuzerja: »Magnifico atque Excellentissimo Domino, D. Caspari Sitnick I. V. D. serenissimi principis Caroli \& consiliario Domino suo plurimum observando Typographus dd.«. Nalepljeno je na notranji strani sprednje platnice Camuzijeve De amore atque felicitate libri novem iz leta 1574. 
disciplinarum iam na naslovni strani vsebuje še dve zanimivi zabeležki, ki ju je verjetno zapisal kateri od gornjegrajskih knjižničarjev: »Cathalogu[s] inscriptus lit[erati] Historici profani num[erus] 35« in: »NB: Hic author est inter libros a conc[ilio] Trid[entino] Prohibitos ut patet ex indice librorum prohibitoru[m] prima[e] classis litt[era] P.«

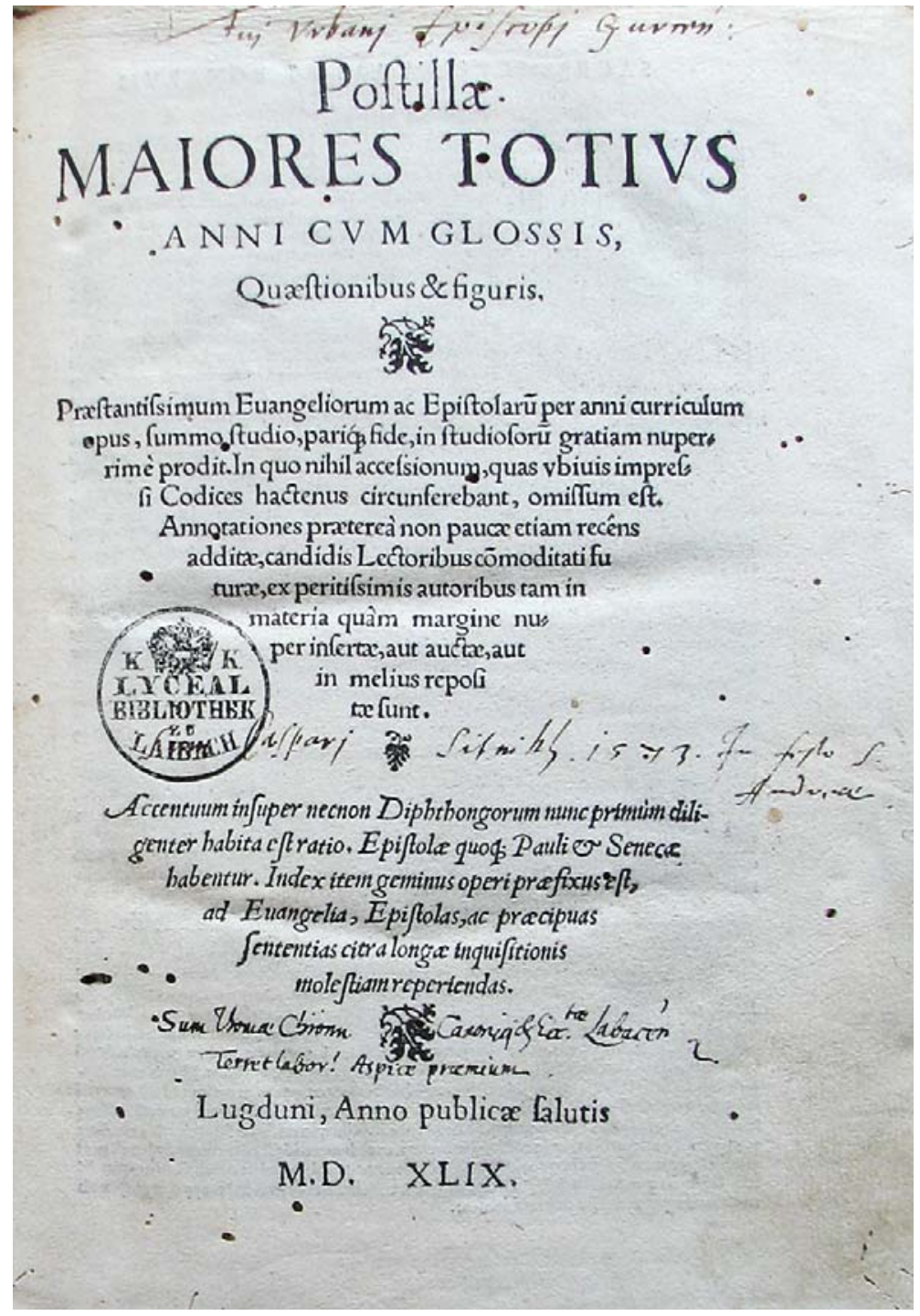

Slika 5: Žitnikova in Hrenova zabeležka ter (Žitnikova?) zabeležka o predhodnem lastništvu krškega škofa Urbana.

V: Guillaume d'Auvergne: Postillae maiores totius anni.

GS II 15227 (naslovna stran). 
Kompilacija priložnostnih pesnitev in govorov, ki ji je dodan tudi seznam rektorjev dunajske univerze (Miscellanea selectissima, signatura GS I 6115), vsebuje zaznamek knjižnice ljubljanskega samostana bosonogih avguštincev: Est Con[ven]tus S[ancti] Josephi Discalceatorum Labac[ensis]. Nad incipitom De imitatione Christi, ki je privezana k Processus Belial, pa je zabeležka neznane roke: »De imitatione Christi Thomae Montis S. Angelis Canonici Regularis (?) liber I.«

\section{Razprava}

Zaznamki in zabeležke v Žitnikovih knjigah kažejo, da je svoje knjige bral in uporabljal ter jih ni kupoval le zaradi zbirateljstva. Le dvanajst od tridesetih do sedaj odkritih zvezkov ne vsebuje nobenih drugih rokopisnih dodatkov razen lastniških vpisov. Skoraj polovica knjig ima mehko pergamentno (humanistično študijsko) vezavo. Zvezki, ki vsebujejo le eno delo, so prej izjema kot pravilo, kar tako kot številni Žitnikovi rokopisni dodatki sporoča, da so bile knjige namenjene predvsem uporabi oziroma branju.

Nekatere zabeležke razkrivajo, da je Gašper Žitnik najvišji akademski naziv najverjetneje pridobil leta 1571 oziroma med letoma 1567 in 1571 ter prinašajo njegov osebni moto. Razkrivajo tudi, da si je Žitnik knjige izmenjeval s sorodniki, prijatelji, znanci in sodobniki. Zabeležka iz časa po Žitnikovi smrti v d'Auvergnovih Postillae maiores totius anni, posredno potrjuje, da je Žitnikove knjige nasledil njegov nečak Tomaž Hren, ki je v njej podpisan kot ljubljanski kanonik. Pogoste so tudi zabeležke o kraju in mestu nakupa (prejema ali izročitve $\mathrm{v}$ dar) posameznih knjig.

Pregled knjižnih vsebin, ki jih je Žitnik kupil ali prejel v dar, kaže, da je poleg pravne literature, ki jo je potreboval pri svojem študiju, kasneje pa pri vsakdanjem delu in jo je tudi najintenzivneje komentiral, v svojo knjižno zbirko vključil še številne druge vsebine; od antične in renesančne filozofije, zgodovine, teologije in krščanske duhovnosti pa vse do sodobne priložnostne poezije, dramatike in satire ter enciklopedičnih del. Na Žitnikovo humanistično izobrazbo poleg vsebine njegovih knjig kažejo tudi številne antične sentence oziroma izreki ter drugi citati, ki jih je zabeležil na notranjih straneh platnic ali predlistih. Verjetno si jih je izpisoval oziroma zapisoval tako za študijske in delovne potrebe kot tudi iz osebnih razlogov. Ni presenetljivo, da je najbolj komentirana Žitnikova knjiga učbenik filozofije s Porfirijevim uvodom v dialektiko in šestimi Aristotelovimi razpravami.

Med daljšimi zapiski je posebej zanimiva in skrivnostna besedna igra o pogubi, ljubezni, krivdi in slavi, povezana $\mathrm{z}$ vojvodinjo Biankho (Bianco?) $\mathrm{v}$ prvi izdaji Corradijeve Templum omnium iudicium pontificiae, cesareae, regiae, inferiorisque 
potestatis iz leta 1575. Iz razpoložljivih podatkov o Žitnikovem življenju je sicer težko nedvoumno ugotoviti ozadje nastanka in povode za ta zapis. Prav tako ni mogoče ugotoviti, ali gre za odlomek kakšnega daljšega besedila. Najverjetneje se besedilo nanaša na ljubico in kasnejšo ženo Francesca I. Medičejskega, Bianco Capello, ki je po poroki s toskanskim nadvojvodo leta 1579 postala izjemno priljubljena $\mathrm{v}$ rodnih Benetkah in tudi širše, $\mathrm{v}$ njeno čast pa so napisali nekaj pesnitev in naslikali portret, ki so si ga v Benetke hodili ogledovat številni častilci (Van Kessel, 2010, 279-291).

\section{Sklep}

Gašper Žitnik je bil v prvi vrsti pravnik in pomembna politična osebnost, ki je nekako izginila iz zgodovinskega spomina. Vsekakor je sodil v krog kranjske oziroma štajerske izobraženske humanistične elite 16. stoletja. To je razvidno tudi iz vsebine knjig, ki jih je zbral v svoji zasebni knjižni zbirki, ter rokopisnih zabeležk, ki jih te vsebujejo. Tudi če o Žitniku ne bi vedeli skorajda ničesar, bi bilo iz njih mogoče razbrati precej podrobnosti o njegovem življenju in delu. Zato so tovrstne raziskave, prav tako kot raziskave arhivskih in drugih zgodovinskih virov, nadvse koristne za rekonstrukcijo podatkov o bolj ali manj znanih osebnostih iz naše preteklosti. $\mathrm{Ob}$ nesporni biografski in bibliografski vrednosti pa prinašajo še obilico posrednih informacij o bralnih navadah ter sorodstvenih in prijateljskih povezavah nekdanjih bralcev oziroma lastnikov knjižnic in knjižnih zbirk.

\section{Bibliografija}

\section{Vir}

Bücherkatalog des Diskalzeatenklosters zů Laibach, Ljubljana, NUK, Ljubljana, Ms 1944.

\section{Literatura}

Golob, N., Belial, procurator infernalis ali kdo je v resnici kriv, Ars \& Humanitas V/2, 2011, str. 49-63.

Golob, N., Reflections on some expressions of Bohemian art around 1400 in Slovenia, Codices manuscripti. Supplementum 6, 2012, str. 56-62.

Gspan, A.,Badalić, J., Inkunabule v Sloveniji, Ljubljana 1957.

Južnič, S., Najstarejši ohranjeni knjižnični katalog na Slovenskem, 1. del: (ob 325-letnici smrti Filipa Terpina v Trubarjevem letu 2008), Knjižnica 52/1, 2008, str. 7-40.

Južnič, S., Najstarejši ohranjeni knjižnični katalog na Slovenskem, 2. del: (ob 325-letnici smrti Filipa Terpina v Trubarjevem letu 2008), Knjižnica 52/3, 2008, str. 7-37. 
Simoniti, P., Sloveniae scriptores latini recentioris aetatis: opera scriptorum latinorum Sloveniae usque ad annum MDCCCXLVIII typis edita: bibliographiae fundamenta. Zagreb 1972.

Simoniti, P., Humanizem na Slovenskem in slovenski humanisti do srede XVI. stoletja, Ljubljana 1979.

Simoniti, P., Med knjigami iz stare gornjegrajske knjižnice, v: Med humanisti in starimi knjigami, Ljubljana 2007, str. 271-315.

Simoniti, P., Še nekaj inkunabul v slovenskih knjižnicah, v: Med humanisti in starimi knjigami, Ljubljana, 2007, str. 316-332.

Stefan, K., Zgodovina C. kr. Študijske knjižnice v Ljubljani, Ljubljana 2009.

Svoljšak, S., Kocjan, U., Provenience starih tiskov Narodne in univerzitetne knjižnice, Ljubljana 2013.

Valenčič, V., pod geslom: Gašper Žitnik, Slovenski biografski leksikon, XV, Ljubljana 1991, str. 976.

Van Kessel, E., Staging Bianca Capello: painting and theatricality in sixteenth-century Venice, Art History 33 (2), 2010, str. 279-291.

Vidmar, L., Prepovedane knjige na Kranjskem od indeksa Pavla IV. (1559) do indeksa Pija VI. (1786): Libri prohibiti v Semeniški knjižnici. Svetovne književnosti in obrobja (ur. Juvan M.), 2012, str. 233-262. 


\section{Dodatek: seznam knjig Gašperja Žitnika $v$ Narodni in univerzitetni knjižnici ${ }^{5}$}

ALDOBRANDINI, Silvestro: Institutiones iuris. Lugduni, 1552. GS 017628.

ARISTOTELES: Elenchorum libri II. Viennae Austrae, 1553. GS I 6905.

ARISTOTELES: Liber praedicamentorum, 1550. GS I 743.

ARISTOTELES: Peri Hermeneias libri II, 1551. GS I 6754.

ARISTOTELES: Posteriorum analiticorum libri II, 1552. GS I 6903.

ARISTOTELES: Priorum analiticorum libri II, 1551. GS I 6915.

ARISTOTELES: Topicorum libri VIII. Viennae Austriae, 1553. GS I 6904.

BEGARDI, Phillip: Index sanitatum, 1539. GS II 11845.

BELLARMATI, Marcantonio: Annotationes quaedam, 1551. GS 017647.

BONACOSSA, Ippolito: Tractatus in materia equorum, 1574. GS 017638.

BRACCIOLINI, Poggio: Opera, collatione emendatorum exemplarium recognita, 1538. GS II 1528.

CAMUZIO, Andrea: De amore atque felicitate libri novem, 1547. GS II 4402.

CAPECE, Antonio: Decisiones novae Sacri Regii Concilii Neapolitani, 1547. GS 017772.

CARPENTIER, Pierre: Epistola ad Franciscum Portum Cretensem, 1573. GS I 2997.

CAVALLINI, Gaspare: Tractatus de evictionibus, 1571. GS 017635.

CHAROPUS, Andreas: Epithalamia in honorem optimi et clarissimi viri, dn. Martini Reuchelii ... [et] ornatissimae virginis Elisabethae, honestissimi viri, dn. Joannis Eberstorferi ... filiae, 1563. NUK: GS I 6128.

CHOPPIN, René: De privilegiis Rusticorum: lib. III, 1575. GS I 16945.

CONTARINI, Gasparo: De magistratibus, \& res publica Venetorum libri quinque, 1544. GS 017758.

CORRADI, Lancelotto: Templum omnium iudicum pontificiae, caesareae, regiae, inferiorisque potestatis, 1575. GS II 17622.

COSTAFORTI, Iuvenalis a: Commentaria in quinque titulos Institutionum D. Iustiniani, 1598. GS 017012.

CUSPINIANUS, Johannes: Der namhaftigen kay. Ma. und dreyer Kunigen zu Hungern Beham und Poln Zamenkumung und Versamlung so zu Wienn in dem Heymonat, 1515. NUK: GS I 6130.

D'ADDA, Ferdinando: Ad omnes iuris civilis interpretes, ac eius disciplinae studiosos, contra iurisprudentiae vituperatores Oratio, 1546. GS 017649.

5 Posamezna enota obsega ime in priimek avtorja, skrajšan naslov, leto izida in signaturo. 
DE electione et inauguratione Maximiliani Austrij II. Rom. regis, Francofurti ad Moenum, anno 1562, 1563. GS I 6120.

DONEAU, Hugues: Commentarius ad titulum digestorum, de praescriptis verbis, \& in factum actionibus, 1574. GS 017640.

EDER, Georg: Catalogus rectorum \& illustrium virorum archigymnasii Viennensis, 1559. GS I 6115.

EISENGREIN, Martin: Ecclesia catholica a novatorum calumniis, per iudices omni exceptione maiores, 1576. GS 015146.

EPISTOLA recens ex Romana urbe in Germaniam missa, 1577. GS I 2999.

EPITHALAMIA in honorem pietate et eruditione praestantis viri Christophori Eysneri Hydropolitani ... [et] honestissimae matronae Agnetis Puchlerin viduae relictae prudentissimi viri Domini Georgij Grammostetteri, med 1553 in 1565. GS I 6132.

EPITOME solenniorum, quae in auspicatum adventum invictiss. ac sacratiss. Rom. Caesaris D.N. Maximiliani, Bohemiae Regis et Archiducis Austriae, 1563. GS I 733705.

EXPOSITIO sub canonem missae, 1470. TI II 12127.

FIOCCHI, Andrea Domenico: L. Fenestellae De magistratibus, sacerdotí́sque Romanorum libellus, iam primum nitori suo restitutus. Pomponii Laeti itidem De magistratibus et sacerdotiis, et praeterea de diversis legibus Romanorum, 1548. GS 017756.

FRISCHLIN, Nikodem: Operum poeticorum, 1585. R 01718.

GIGANTI, Girolamo: Responsa familiaria in materia ecclesiasticarum pensionum ... Hieronymi Gigantis, 1562. GS I 16635.

GIUNTI, Ludovico: Responsum pro uxore, 1570. GS I 16634.

GUILLAUME d'Auvergne: Postillae maiores totius anni, 1549. GS II 15227.

GÜNDERRODE, Heinrich von: De veris principiis artis dimicatoriae, 1579. NUK: GS I 2998.

HEGENDORPH, Christoph: Opuscula quae in hoc libro continentur. Epitome Tyrocinii iuris civilis. In titulum lib. III. digestorum scholia. Oratio de praeclaris rebus gestis Iustiniani Imperatoris. Enarratio nonae Philippicae Ciceronis, in qua multa de laudibus Servii Sulpitii, memorabile exemplum perfecti iurisconsulti proponitur, 1540. NUK: GS 017766.

HOFFMEISTER, Johann: Verbum dei carnem factum, 1545. GS I 14287.

HORTENSIUS, Lambertus: Ennarationes in sex priores libros Aeneidos Vergilianae, 1559. GS II 1229. 
HOTMAN, François: De legibus populi Romani liber, 1557. NUK: GS 017757.

EPITOME solleniorum quae in auspiciatum adventum invictiss. Rom. Caesaris D. N. Maximiliani ... [vsebuje tudi:ŽITNIK, Gašper: »In auspicatum et felicem adventum invictissimi ac sacratissimi Rom. Caesaris D.N. Maximiliani Bohemorum Regis, et Austriae archiducis ... congratulatio suppex inclyti archigymnasii Viennensis eiusque alumnorum obsequii ergô pro sua fortuna tenui humiliter exhibita« in ŽITNIK, Gašper: »In augustissimi Rom. et Bohemiae regis, divi Maximiliani secundi ... in patriam reditum ... Carmen gratulatoria«], 1563. GS I 733705.

INVICTISSIMO et potentissimo Romanorum imperatori, divo Ferdinando semperaugusto, Bohemiam nuper ingresso: carmen gratulatorium scholae Ioachimicae, 1558. GS I 6123.

IUSTINIANUS I: Codicis Dn. Iustiniani sacratiss. principis ex repetita praelectione libri XII, 1548. GS 0 17490, GS 017625.

IUSTINIANUS I: Novellarum constitutionum volumen, 1548. GS 017011.

JACOBAEUS, Vitus: Academia Ingolstadiensis Carmine illustrata, 1562. GS I 6124.

JACOBUS de Teramo: Consolatio peccatorum, seu Processus Belial, 1472. Ti II 12127.

JAVELLUS, Chrysostomus: quaestiones super libros Metaphysicae Aristotelis iuxta Thomisticae doctrinae dogmata decisae, 1555. GS 04586.

JOANNES Chrysostomus: Aliquot orationes Graecae et Latinae, 1552. GS 017013.

JODOCUS, Gabriel: Propemptica in discessum optimae spei adolescentum, Iobi et Philippi, 1562. GS I 6137.

JOHANN Kasimir: Brevis et luculenta expositio causarum, quibus adductus Illustriss. Princeps ac Dominus, Dominus Iohannes Casimirus ... hanc expeditionem, ad erigendas res Belgii graviter afflictas, susceperit, 1578. GS I 2922.

KLING, Melchior: Explicatio et continuatio titulorum iuris civilis, \& canonici, [1549]. GS 017765.

LAGUS, Conrad: Methodica iuris traditio, seu ratio compendiaria, 1552. GS 017502.

MANDOSIO, Quintiliano: Glossa facultatum regentis in locum auditioris camerae suffecti, 1576. GS I 16894.

MANTOVA Benavides, Marco: Milleloquii iuris centuria prima, 1561. GS I 16636.

MELA, Pomponius: Libri de situ orbis tres, 1518. G II 201.

MENOCHIO, Giacomo: De adipiscenda, et retinenda possessione amplissima et doctissima commentaria, 1572. GS 017634.

MERCURIUS, Iohannes: In obitum illustrissimae principis dominae Elisabethae Palatinae Rheni, 1563. GS I 6139. 
MIGRATIO Germanorum ex Academia Bononiensi, 1562. GS I 6138.

OLDENDORP, Johann: Index titulorum iuris civilis, 1543. GS 017764.

ORATIONES Viennae Austriae ad Divum Maximilianum Caes. Aug. aliosq[ue] illustrissimos Principes, habitae, 1516. GS I 6129.

PALAMEDE, Giulio: Tabula in Aristotelis, Averroisque opera, 1561. GS II 4398.

PIGNOLATI, Nicolò: Vera resolutio quaestionis, an in pari causa praevaleat causa fisci, sicut praevalet causa dotis, 1551. GS 017650.

PLACENTINUS: In summam institutionum sive elementorum D. Iustiniani sacratissimi principis, nunc primum in lucem aediti libri IIII, 1537. GS II 11846.

PORPHYRIUS: Isagoge in dialecticen, 1550. NUK: GS I 742.

POZZO, Paride del: Tractatus insignis De reintegratione feudorum, 1544. GS II 36199.

PROCESSUS iudiciarius, 1470. TI II 12127.

QUINTILIANUS, Marcus Fabius: Declamationum liber, 1563. GS 0884.

QUINTILIANUS, Marcus Fabius: Oratoriarum institutionum libri XII, 1561. GS 0884.

REUBER, Justus: De testibus methodica traditio, 1574. GS 017639.

SÄLLER, Paul: In nuptias nobili \& magnifici viri, domini Hieronymi Böckh à Leopoltstorff ... dominae Magdalenae ... epithalamion, 1560. GS I 6136.

SÄLLER, Paul: Carmen de sancto Christophoro: in honorem et gratiam, 1560. GS I 6133.

SÄLLER, Paul: Ecloga, qua typus gloriosae Iesu Christi passionis, breviter compraehenditur, 1560. GS I 733811.

SÄLLER, Paul: Chorus musarum, in serenissimi ac potentissimi principis, ac domini do. Maximiliani, 1563. GS I 6133.

SALUTATI, Coluccio: Tractatus de nobilitate legum, 1542. GS 017646.

SARAINA, Gabriele: Singularia, praeclarissima ac imprimis omnibus iurisperitis pernecessaria, ac utilissima, 1558. GS 017603.

SARAINA, Gabriele: Tractatus de syndicatu variorum authorum, 1571. GS I 16893.

SCHEDE, Paul: Epithalamion in nuptias ... viri, DN. Sebastiani Froelich Graecensis Styri [et] honestissimae virginis Marthae, 1563. GS I 6125.

SECKERWITZ, Johann: Epithalamion in nuptias ... Abrahami Iorgeri à Tolleth ... [et] ... virginis Barbarae, 1563. GS I 6126.

SEILER, Raphael: Remissiones vel, ut alii commodius dici arbitrantur, relegationes instar mercurialis statuae indicantes, 1571. S II 17624.

SKALIĆ, Pavao: Encyclopaediae, seu Orbis disciplinarum, 1559. GS I 4833. 
SLEIDANUS, Johannes: De statu religionis et reipublicae, Carolo Quinto, Caesare, commentarii, 1556. GS II 3413.

STROTSCHIUS, Ebrahimus: Türckischer Botschaft, 1562. GS I 6121.

TALHAMER, Dionysius: Oratio in funere clarissimi viri, Lucae Guettenfelder, 1562. GS I 6116.

THEOBALDUS: Errores Judaeorum ex Talmud extracti, 1473. TI II 12127.

THOMAS a Kempis: Imitatio Christi, 1473. TI II 12127.

TORQUEMADA, Juan de: De pontificis maximi consiliiq[ue] generalis auctoritate ad Basileensium oratorem responsio, 1563. GS I 16633.

TRITHEMIUS, Johannes: Chronicon insigne monasterii Hirsaugiensis, 1559. GS II 16172.

VIOLA, Pietro: Oratio in funere Hieronymi Cagnoli, 1551. GS 017648.

VITERBO, Gottfried von: Pantheon, sive Universitatis libri, qui chronici appellantur, 1559. GS II 16173.

VOERTHUSIUS, Joannes: Academiae veteris et novae ad divum Maximilianum Austrium II. Romanorum, Bohemiae, etc. regem, in coronatione Francofurtensi gratulationis ergo legatio, 1563. GS I 6119.

VUOLFHARDUS, Adrianus: Ioannis episcopi quinque ecclesiarum panegyricus praeceptori Guarino Veronensi, praefatio, 1512. GS I 6131.

WEIDNER, Paul: Sententiae hebraicae ad vitae institutionem perutiles breviter explicatae, 1563. GS I 6127.

WARHAFFTIGE Beschreibung, welcher gestalt die Königkliche wirde Maximilian, und Frewlin Maria, geborne Königin auss Hispanien, dero Gemahel, zů Böhemischen König und Königin in Prag den 20. Septembris, dieses 1562. jars gekrönt worden, 1563. GS I 6118.

WIDEBRAM, Friedrich: Epithalamion scriptum Vito Winshemio ... \& sponsae pudicissimae virgini Euphrosynae, filiae Gregorij Pontani, 1559. GS I 6134. 


\section{Sonja Svoljšak}

\section{Gašper Žitnik in njegove knjige}

Ključne besede: Gašper Žitnik, osebne knjižne zbirke, rokopisne zabeležke, 16. stoletje

Gašper Žitnik (ca. 1535-1585) je doktoriral iz obojega prava na dunajski univerzi. Bil je palatinski grof, svetovalec notranjeavstrijske vlade in pomembna politična osebnost v obdobju kranjske in štajerske protireformacije. Kot stric škofa Tomaža Hrena (1560-1630) je močno vplival na njegovo vzgojo, izobraževanje in kariero. V mladosti se je priložnostno ukvarjal s pesnjenjem, vse svoje življenje pa je zbiral knjige ter vanje zapisoval različne podrobnosti, ki se nanašajo na njegov študij, življenje in delo. Prispevek podaja pregled Žitnikovih knjig, ki jih hrani Narodna in univerzitetna knjižnica, s poudarkom na tistih, ki vsebujejo pomembnejše Žitnikove rokopisne zabeležke in pripise nekaterih njegovih sodobnikov. Odkritja skozi tovrstne sekundarne podatke dopolnjujejo dosedanja dognanja o Žitnikovem življenju in delu ter razkrivajo nekaj podrobnosti o njegovih bralnih navadah oziroma njegovem odnosu do knjig. 


\section{Sonja Svoljšak}

\section{Gašper Žitnik and His Books}

Keywords: Gašper Žitnik, personal book collections, hand-written notes, $16^{\text {th }}$ century

Gašper Žitnik (ca. 1535-1585) was a jurist, a doctor of law from the Vienna university, a Count palatine, an Inner-Austrian government councillor and an important political figure in Carniolian and Styrian Counter-Reformation. He was also Bishop Tomaž Hren's (1560-1630) uncle and had important influence on his upbringing, education and career. Besides being an occasional poet in his youth, he was also a book collector and he liked to inscribe various details about his study, work and personal life into his books. The paper gives an overview of Žitnik's books, which are kept in the National and University Library, with an emphasis on his handwritten notes and some other peoples' hand-written notes in his books which are of significance. The findings complement the already known facts about Žitnik's life and work through this secondary information while also revealing some details about the relation between his books and him as their reader. 